\title{
Formation of organic deposits on low-preassure reverse osmotic membranes in treating water from surface sources
}

\author{
Yu Dan Su', Alexei G. Pervov², Xuan Quyet Nguyen² \\ ${ }^{1}$ RAIFIL China, CSM official representative in Russia; Shanghai, China; \\ ${ }^{2}$ Moscow State University of Civil Engineering (National Research University) (MGSU); \\ Moscow, Russian Federation
}

\begin{abstract}
Introduction. In this paper, we investigate the interaction of organic pollutants with nanofiltration and reverse osmosis membranes in natural water on the basis of experimental data and available literature information. The rates of formation of various organic deposits (humic acids changing the water colour and forming low-molecular organic compounds characterised by an oxidation index) on membranes during purifying river and pre-treated water are presented.

Aim: To determine the required efficiency of removing organic substances from surface waters at the pre-treatment stage prior to water treatment by reverse osmosis on the basis of measuring the rates of adsorption of organic substances on membranes and predicting the amount of as-formed organic deposits.

Methods and materials. Methods for determining the adsorption rate of organic pollutants using gas-liquid chromatography and total carbon determination are described. The advantages of spectrogram analysis in assessing water quality are specified. The formation rates of high- and low-molecular organic substances, which produce colouring and characterise water oxidisability, respectively, were determined using a membrane test unit.

Results. According to the rates of forming organic deposits on membranes both during the processing of river water with a colour of $60 \mathrm{PCU}$ and purified (tap) water with a colour of $18 \mathrm{PCU}$, organic substances adsorbed on membranes are shown to have little effect on the efficiency of the reverse osmosis process. In addition, the rate of depositing organic substances on the membranes under study is established to be significantly lower than that using sparingly soluble salts (calcium carbonate). Conclusion. Our results demonstrate that organic deposits formed on the membranes under study have an insignificant effect on the membrane performance. Therefore, pre-treatment aimed at removing organic substances when purifying natural waters with colour indices of up to $60 \mathrm{PCU}$ is not required.
\end{abstract}

KEYWORDS: membrane water demineralisation, reverse osmosis, nanofiltration, pretreatment, organic impurities, removal efficiency, colour reduction, membrane adsorption of organic impurities, molecular weight distribution

Acknowledgments: The authors express their gratitude to the Russian Foundation for Basic Research for the financial support of this study in the framework of the project 19-08-00982. The authors are also thankful to Natalya B. Motovilova for her assistance in determining the absorption spectra of organic substances in water samples.

FOR CITATION: Yu Dan Su, Alexei G. Pervov, Xuan Quyet Nguyen. Formation of organic deposits on low-preassure reverse osmotic membranes in treating water from surface sources. Vestnik MGSU [Monthly Journal on Construction and Architecture]. 2019; 14:9:1180-1195. DOI: 10.22227/1997-0935.2019.9.1180-1195 (rus.).

\section{Изучение образования органических осадков на низконапорных обратноосмотических мембранах при обработке воды из поверхностных водоисточников}

\author{
Ю Дан Суㅜㄹ А.Г. Первов², Суан Кует Нгуен² \\ ${ }^{1}$ RAIFIL China офиииальный представитель компании CSM в России; г. Шанхай, Китай; \\ ${ }^{2}$ Национальный исследовательский Московский государственный строительный университет
}

(НИУ МГСУ); г. Москва, Россия

\begin{abstract}
АННОТАЦИЯ
Введение. На основе экспериментальных данных и обобщения информации, изложенной в литературе, рассмотрены вопросы взаимодействия органических загрязнителей природной воды с нанофильтрационными и обратноосмотическими мембранами. Цель исследования - определение требуемой эффективности удаления из поверхностных вод органических веществ на стадии предочистки перед обработкой воды методом обратного осмоса путем установления скоростей адсорбции на мембранах органических веществ и прогнозирования количества накопленных на мембранах органических отложений.
\end{abstract}


Материалы и методы. Описаны методики определения скоростей адсорбции органических загрязнений с использованием методов газожидкостной хроматографии и определения общего углерода, представлено обоснование применения анализа спектрограмм для оценки качества воды. На испытательном мембранном стенде зафиксированы скорости образования в мембранных аппаратах осадков высокомолекулярных органических веществ, образующих цветность, и низкомолекулярной органики, характеризующей окисляемость.

Результаты. Представлены результаты определения скоростей образования органических осадков различной природы (гуминовых кислот, образующих цветность, и низкомолекулярных органических соединений, характеризующихся показателем окисляемости) на мембранах при обработке речной воды и воды, прошедшей предочистку. Полученные данные определения скоростей образования на мембранах органических отложений как при обработке речной воды с цветностью $60^{\circ}$ платино-кобальтовой шкалы (ПКШ), так и очищенной (водопроводной) воды с цветностью $18^{\circ}$ ПКШ, показывают, что адсорбированные на мембранах органические вещества мало влияют на эффективность процесса обратного осмоса и скорость образования отложений органических веществ идет на мембранах гораздо медленнее осадкообразования малорастворимых солей (карбоната кальция).

Выводы. Результаты экспериментов продемонстрировали, что образующиеся на мембранах органические осадки слабо влияют на показатели работы мембран, поэтому при очистке природных вод с показателями цветности до $60^{\circ}$ ПКШ предочистки по органическим веществам не требуется.

КЛЮЧЕВЫЕ СЛОВА: мембранное обессоливание воды, обратный осмос, нанофильтрация, предочистка, органические загрязнения, эффективность удаления органики на нанофильтрационных и обратноосмотических мембранах, снижение цветности, адсорбция органических загрязнений на мембранах, молекулярно-массовое распределение

Благодарности. Авторы выражают благодарность Российскому фонду фундаментальных исследований за финансовую поддержку данного исследования в рамках проекта 19-08-00982. Авторы также благодарят Н.Б. Мотовилову за помощь в определении спектров поглощения органических веществ в пробах воды.

для цитировАНИЯ: Ю Дан Су, Первов А.Г., Суан Кует Нгуен. Formation of organic deposits on low-preassure reverse osmotic membranes in treating water from surface sources // Вестник МГСУ. 2019. Т. 14. Вып. 9. С. 1180-1195. DOI: 10.22227/1997-0935.2019.9.1180-1195

\section{INTRODUCTION}

Membrane reverse osmosis and nanofiltration methods are widely used for ensuring drinking and industrial water supply [1-6]. Reverse osmosis and nanofiltration membranes effectively retain both high- and low-molecular organic substances, which explains their extensive application in drinking and industrial water supply. However, the presence of organic substances in the water being purified causes concern among developers of membrane plants due to the possibility of their deposition on the membranes [3].

Publications devoted to the formation of organic contaminants on reverse osmosis membranes have thus far reported conflicting opinions [1-18]. On the one hand, enormous practical experience has been accumulated in application of reverse osmosis and nanofiltration systems for the treatment of surface and groundwater for drinking and industrial water supply $[7,8-15$, $22-35]$. On the other hand, a number of authors have argued that dissolved organic contaminants should be removed from the water entering the reverse osmosis plants at the pre-treatment stage. Such residues were presumed to react with the surface selective layer of membranes, thus causing its further deterioration [1-6, $8-19,21]$. Russian researchers reported similar findings during the initial periods of the implementation of reverse osmosis for treating surface waters for energy facilities [13-15, 33-37]. Failures in the operation of reverse osmosis units were associated with the presence of organic substances both in source water and membranes [2-4, 19-23]. However, the results of numerous further studies [34] have shown that changes in the performance of membrane devices should be studied comprehensively, taking into account the influence of various factors, in particular, the formation of crystalline deposits of sparingly soluble salts, an increase in the hydraulic resistance of membrane channels due to the deposition of turbulent grids in the nodes, etc. [14, 15, 23, 34, 35]. Thus, Harvey Winters [5] found humic acids to form a thin adsorption layer on the membrane surface, causing no irreversible deterioration in membrane performance.

In this respect, a serious breakthrough was the application of the ultrafiltration method for the pre-treatment of drinking water from surface water sources [7, 14-26]. However, the efficiency of removing organic substances from water using ultrafiltration units did not eventually exceed that of such conventional methods as coagulation and filtration. The process of depositing organic substances on membranes can be investigated by determining the molecular mass distribution of organic contaminants in natural waters using the gas-liquid chromatography method $[23,26]$. 


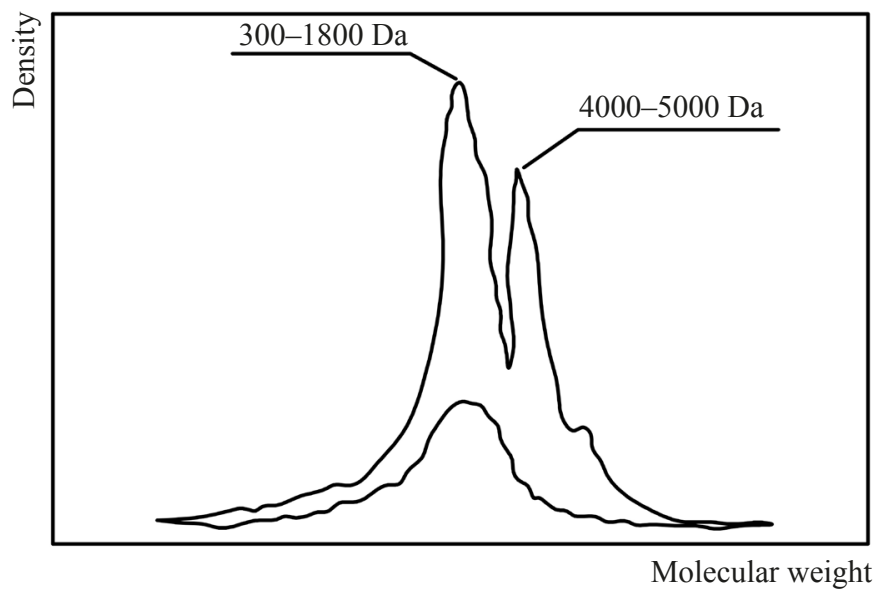

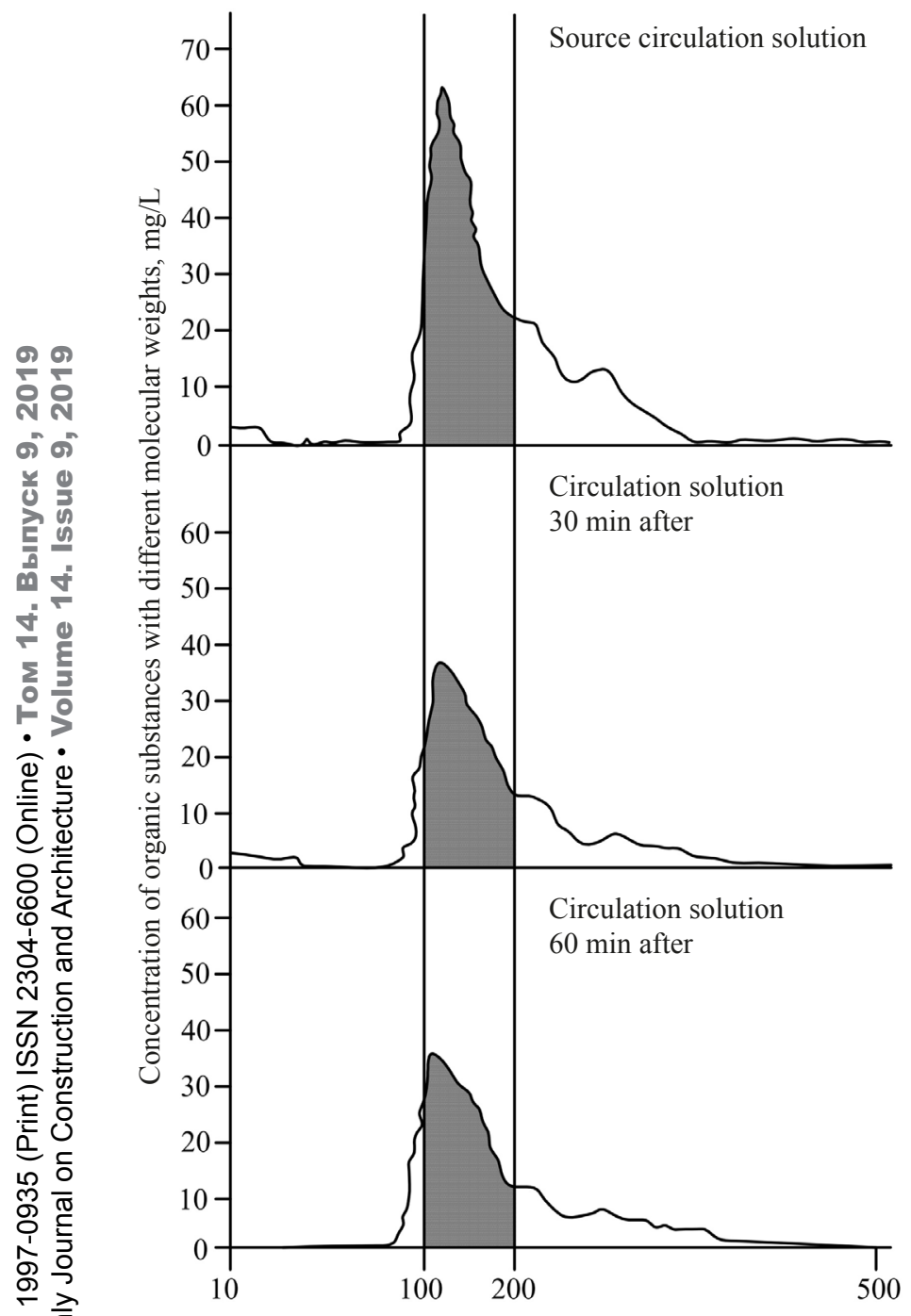

Fig. 1. Comparison of the molecular weight distribution for organic substance in river water and in the filtrate from a nanofiltration membrane unit [23]
Fig. 2. Molecular weight distribution of organic compounds in water samples [34]
Figure 1 demonstrates the molecular weight distribution established for natural river water and the filtrate obtained in [23]. The evaluation of the concentrations of various organic substances with different molecular weights in water samples allows identification of substances reacting most actively with the membrane sur- face. Figure 2 presents the molecular mass distribution (MMD) of the solute at various stages of the experiment conducted in the circulation mode [26]. Figure 3 displays the rates of adsorption of organic substances and their effect on the productivity and selectivity of the membranes. 

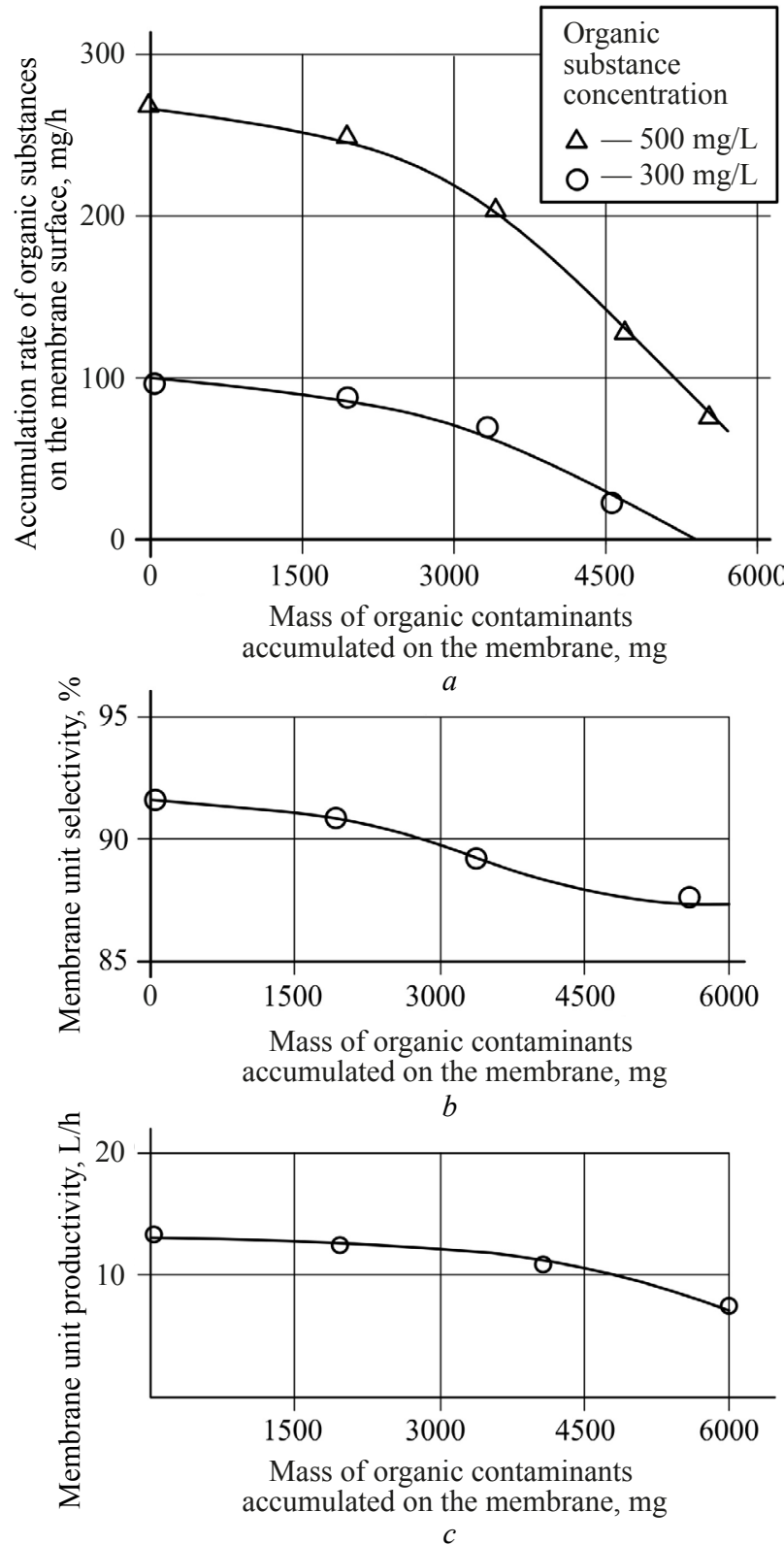

Fig. 3. The influence of organic contaminants on the performance and selectivity of membranes [34]

Similar experiments in the circulation mode were carried out by James Taylor [6, 34], in which the concentration of total organic carbon was determined in a circulating solution using the photoelectrocolorimetric method (see Fig. 4).

In this article, we set out to determine the deposition rate of organic substances with different molecular weights on the example of water from the Moscow water supply system and surface river water, as well as to investigate the influence of the membrane material and its operational hydrodynamic regime on the rate of organic deposition. To identify the nature and concentration of substances accumulated on membranes, we applied spectrograms with characteristic "peaks" corresponding to the maximum concentrations of organic

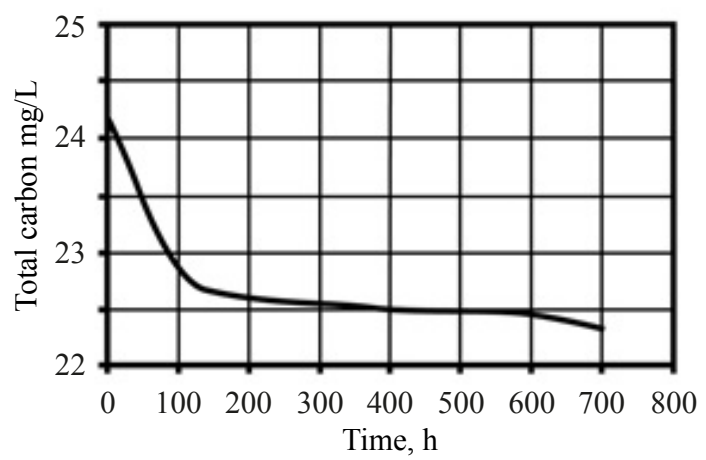

Fig. 4. Experimental results of the total carbon determination in a circulating solution [36] substances with different molecular weights [35] rather than expensive chromatographic methods. 


\section{MATERIALS AND METHODS}

In previous studies, main patterns for the accumulation of organic substances on membranes were determined [25]. Experiments were conducted and conclusions were made for cases of natural water purification at high colour values. Therefore, forecasting and studying the effect of organic substances in surface waters after pre-treatment during the reverse osmosis process presents significant interest.

The schematic view of a laboratory bench for studying the deposition rates of organic substances on the surface of reverse osmosis and nanofiltration membranes is provided in Fig. 5. The experiments were carried out using river (no pre-treatment) and tap water samles with the purification of the latter by coagulation, precipitation and filtration. The deposition rates of colloidal and organic substances on the membranes were determined in the concentration mode. A water sample was placed in the source water tank (1) with subsequent pumping (6) to the membrane unit (3). The speed in the membrane channels and the transit flow value were adjusted using bypass valves (7).
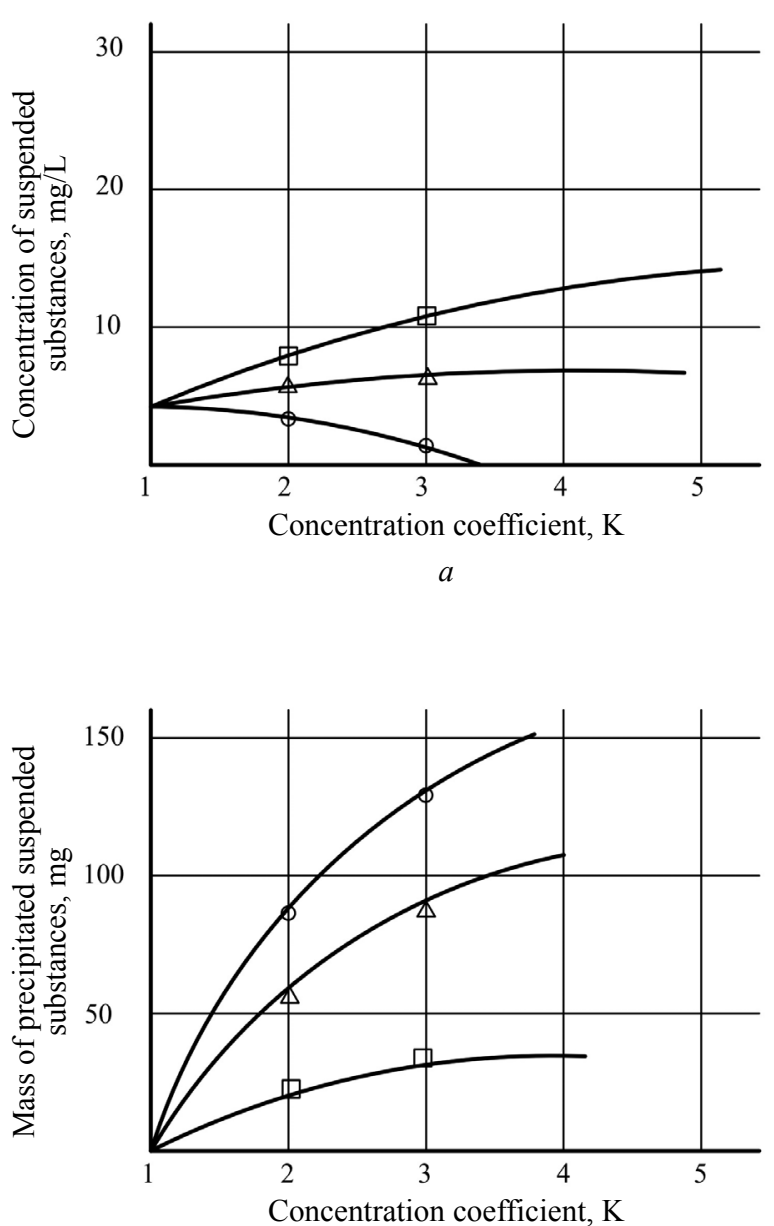

Fig. 6. Deposition rate of suspended and colloidal substances

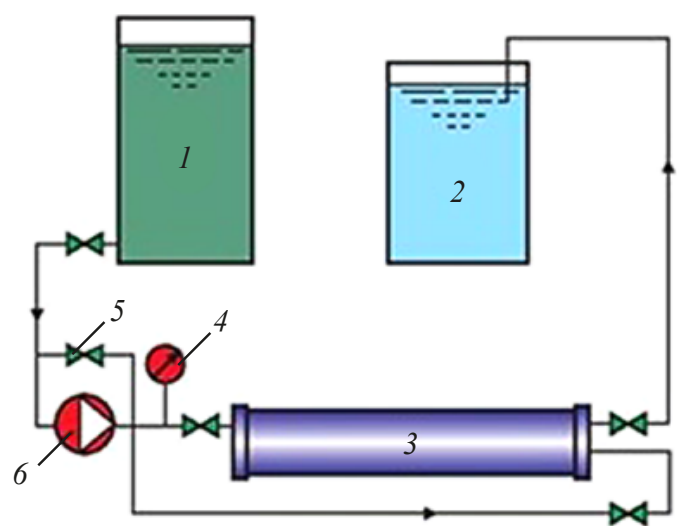

Fig. 5. Schematic view of the experimental bench: 1 - source water tank; 2 - filtrate tank; 3 - rolled membrane element in a pressure housing with reverse osmosis membranes; 4 pressure gauge; 5 - pressure control valve; 6 - pump unit; 7 - bypass crane

Figure 6, $a$ shows the dependence of the cloud number on the $\mathrm{K}$ index of the volume reduction, which was determined as the ratio of the water volume in the tank (1) at the beginning of the experiment to the

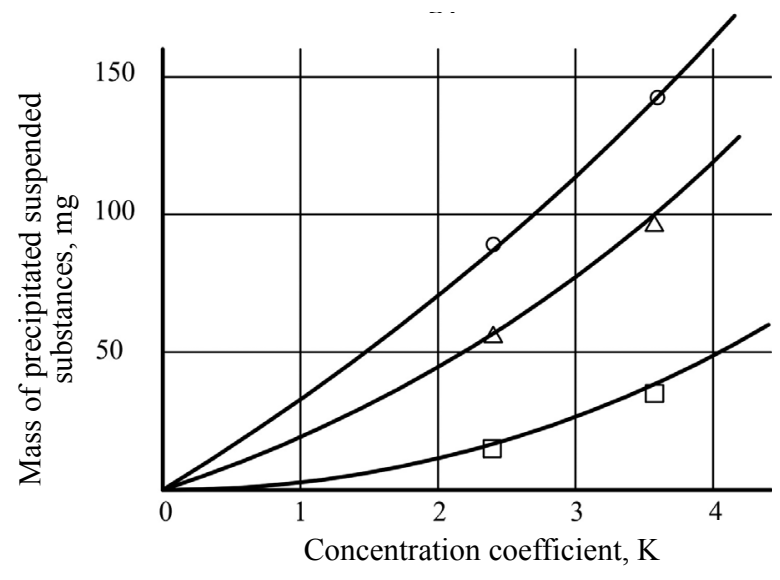

$b$

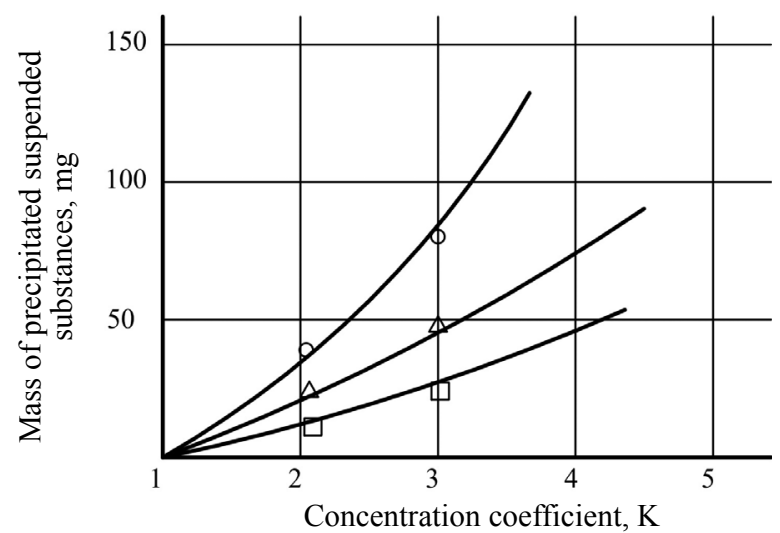

d 
water volume at a given point in time (at the time of sampling). The mass of suspended and colloidal substances on the membranes at each moment of time was determined as the difference between the mass of suspended substances in the tank (1) at the beginning of the experiment and at a given point in time of the experiment (Fig. 6, $b$ ). Deposition rates were determined as tangents of slopes of the dependence curve for the mass of contaminants deposited on the membrane (Fig. 6,c). The values of deposition rates of suspended and colloidal substances are presented in Fig. 6, $d$ depending on the K-values. Obtained as a result of the experiment, the dependences of the colour of river water on the values of $\mathrm{K}$ are presented in Fig. 7.

The membrane adsorption rates of high- and lowmolecular organic substances determined in a circulating mode by the experimental bench are shown in Figure 5. Along with the determination of adsorption rates, the purpose of this series of experiments was to determine the dependences of the adsorption rates on the concentration of organic substances in water. In addition, spectrograms were used to assess changes in water quality during the experiment and to establish those substances that tended to adsorb on the membrane. In order to analyse the mass of dissolved organic substances in water and their interaction with the membrane surface, spectrograms were used in the yellow light range with a wavelength of 420-500 nm. A photoelectric photometer KFK-3 was applied. Optical density spectra of the water samples were obtained in the wavelength range from 300 to $500 \mathrm{~nm}$.

The effectiveness of cleaning surface river water and water from a Moscow water supply was assessed using composite low-pressure reverse osmosis membranes of the BLN type (CSM, Korea) and acetate reverse osmosis membranes of the NTC Vladipor company (Russia). Figure 6 and 7 present the results of an experiment on the treatment of river water and the study of the deposition of suspended and colloidal substances (Fig. 6), as well as organic substances (Fig. 7) on the membranes. Figure 6 presents the results of determining deposition rates of colloidal and suspended substances on reverse osmosis membranes depending on the values of the water transit flow through the membrane unit during the processing of river water. Figure 7 demonstrates the results of a change in the colour index of river water during the processing, i.e. the dependence of the colour values on the $\mathrm{K}$ volume reduction index.

In order to determine changes in the quality of the source water during its contact with the membrane material, experiments were carried out in a circulation mode. The experiments were performed at the laboratory bench shown in Figure 5. In contrast to the concentration mode (Fig. 6-8), the filtrate and concentrate were returned to tank 1 after the reverse osmosis membrane module. In cases when suspended and organic substances did deposit on the membranes, their concentrations in circulating water (estimated by the indicators of cloud number, colour and oxidisability, as well as generally estimated by the curve changes in the spectrograms of water samples) was gradually decreasing over time (Fig. 9-13).

In addition, the effect of the membrane material on the deposition rate of organic substances was studied. Figure 8 displays the results of colour determination of river water, which circulated through membrane units with composite and acetate membranes. Figure 9 presents spectrograms for river $(a)$ and tap water $(b)$ sampled at the beginning of the experiment, one hour and 2 hours after the start of the experiment in a circulation mode. Figure 12 describes the dependences that were used for the calculation of the deposition rates of high(colour forming) and low-molecular (determining oxidisability) organic compounds on the membranes under study. The light absorption spectra of water samples obtained during the experiments are shown in Fig. 13.

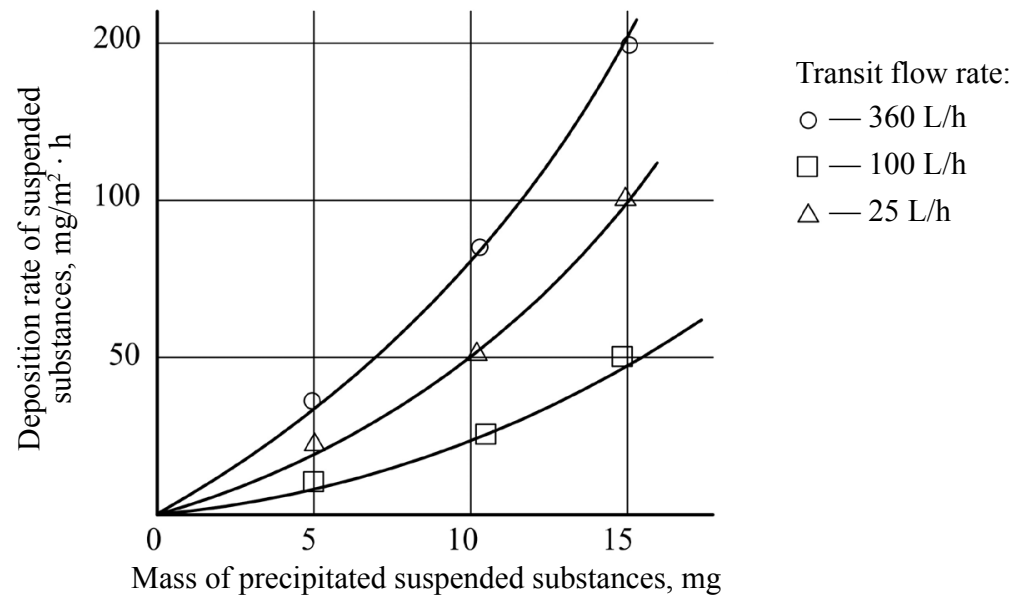

Transit flow rate:

o $-360 \mathrm{~L} / \mathrm{h}$

$\square-100 \mathrm{~L} / \mathrm{h}$

$\triangle-25 \mathrm{~L} / \mathrm{h}$

Fig. 7. Dependence of deposition rates of suspended substances on their concentration 


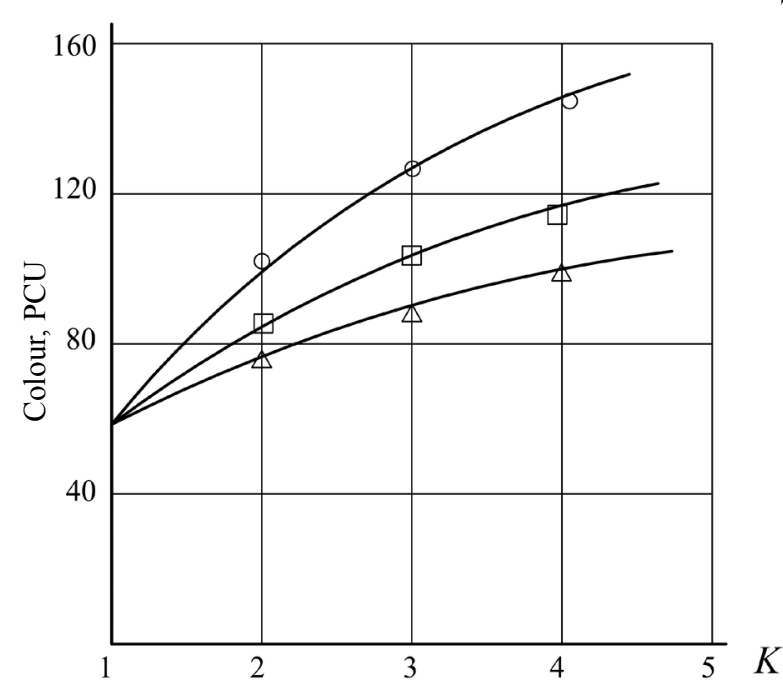

Transit flow rate:

o $-360 \mathrm{~L} / \mathrm{h}$

$\square-100 \mathrm{~L} / \mathrm{h}$

$\triangle-25 \mathrm{~L} / \mathrm{h}$

Fig. 8. Effect of transit flow rate on the organic deposition

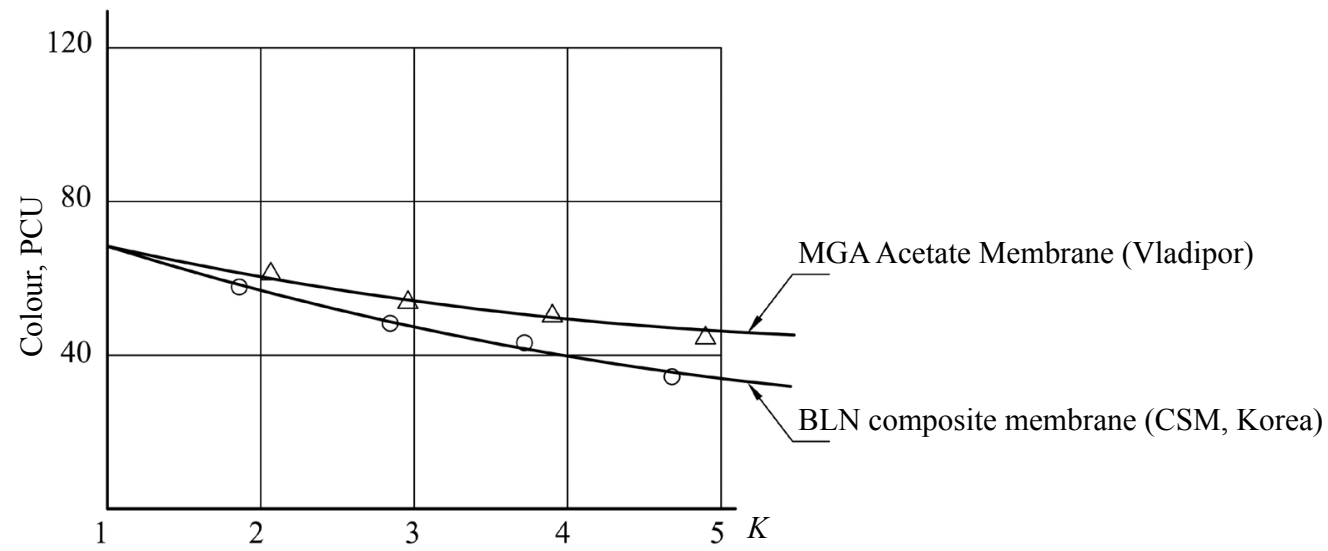

Fig. 9. The effect of membrane material on the adsorption of organic substances

\section{RESULTS}

As can be seen from Figures 6,7 and 8, the transit flow rate has a significant effect on the rate of depositing suspended substances of the membranes and the rate of adsorption of organic compounds on the membrane surface.

As our studies show, cellulose acetate-based membranes appear to be less susceptible to organic pollution than composite ones largely because composite membranes are made of polyamide that exhibits hydrophobic properties. Therefore, composite membranes get quickly contaminated when treating water containing natural organic impurities, presented by hydrophobic colloids in most cases (Fig. 9).

As follows from Fig. $3 a$ and $3 b$, the formation of organic sediments has an insignificant effect on the membrane productivity and selectivity. Accumulation of organic substances on the membrane leads to a decrease in the rate of their adsorption capacity (Fig. 8,a).
Figure $3 c$ and $3 d$ show the dependences of a decrease in the membrane productivity and selectivity on the mass of organics adsorbed on the membrane surface obtained in [25]. These results allow the effect of organic substances contained in water on the operation of membranes to be predicted, as well as the frequency of chemical washes to be determined. Figures 10 and 11 present the deposition rates for suspended organic substances during the operation of the experimental bench in a circulation mode.

In a circulation mode, experiments were conducted to determine the membrane adsorption rates of organic substances with various molecular weights. Figures 10 (a) and $11(a)$ present the results of colour reduction in river and tap water, respectively. Figures $10(b)$ and 11 (b) show the results of determining the amount of organics on membranes depending on the time of the experiment. The adsorption rates for organic compounds are provided in Figures $10(c)$ and $11(c)$. The presentation of the obtained results in the form of dependences 

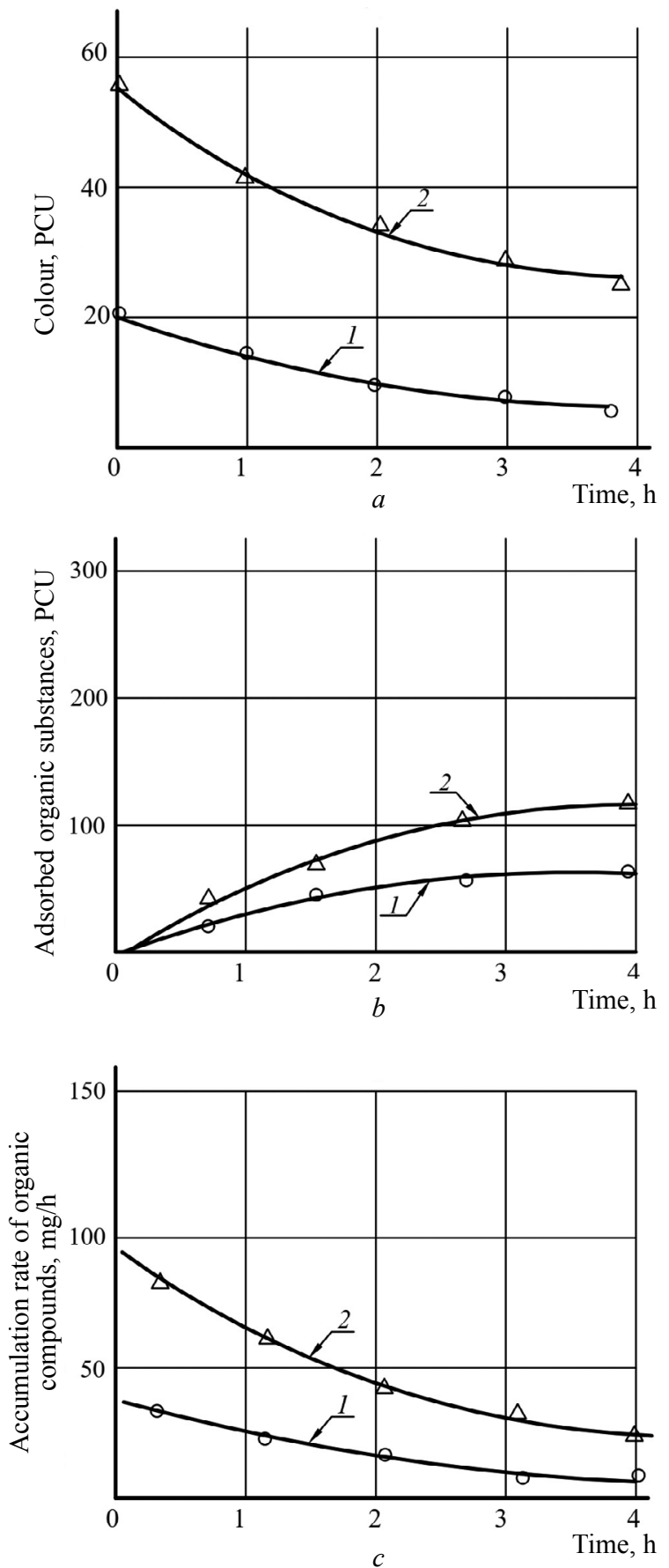

Fig. 10. Deposition rates for colour forming macromolecular compounds: $a-$ a decrease in the concentration of organic substances during the operation of the membrane unit; $b$ - time dependence of adsorbed organic contaminants; $c$ - the results of determining the accumulation rate of organic substances in time; 1 - tap water; 2 - river water

of the adsorption rates for different organic substances on their concentration appears to be of particular interest. The adsorption rate dependences of the colourforming organic compounds on their concentration in the river (curve 1) and tap (curve 2) treated water are presented in Figure 12. It can be seen that the curves for the colour values of 10-20 PCU practically coincide. The difference in values can be explained by the difference in the nature of organic substances and their molecular weights in river water and water after coagulation treatment. The adsorption rates of low-molecular substances determining the oxidisability of water with respect to the values of their concentrations are provided in Figure 12.

Light absorption values for water samples were determined when the unit was operating in a circulation mode, at the beginning of the experiment, as well as after an hour and after 2 hours of operation. 

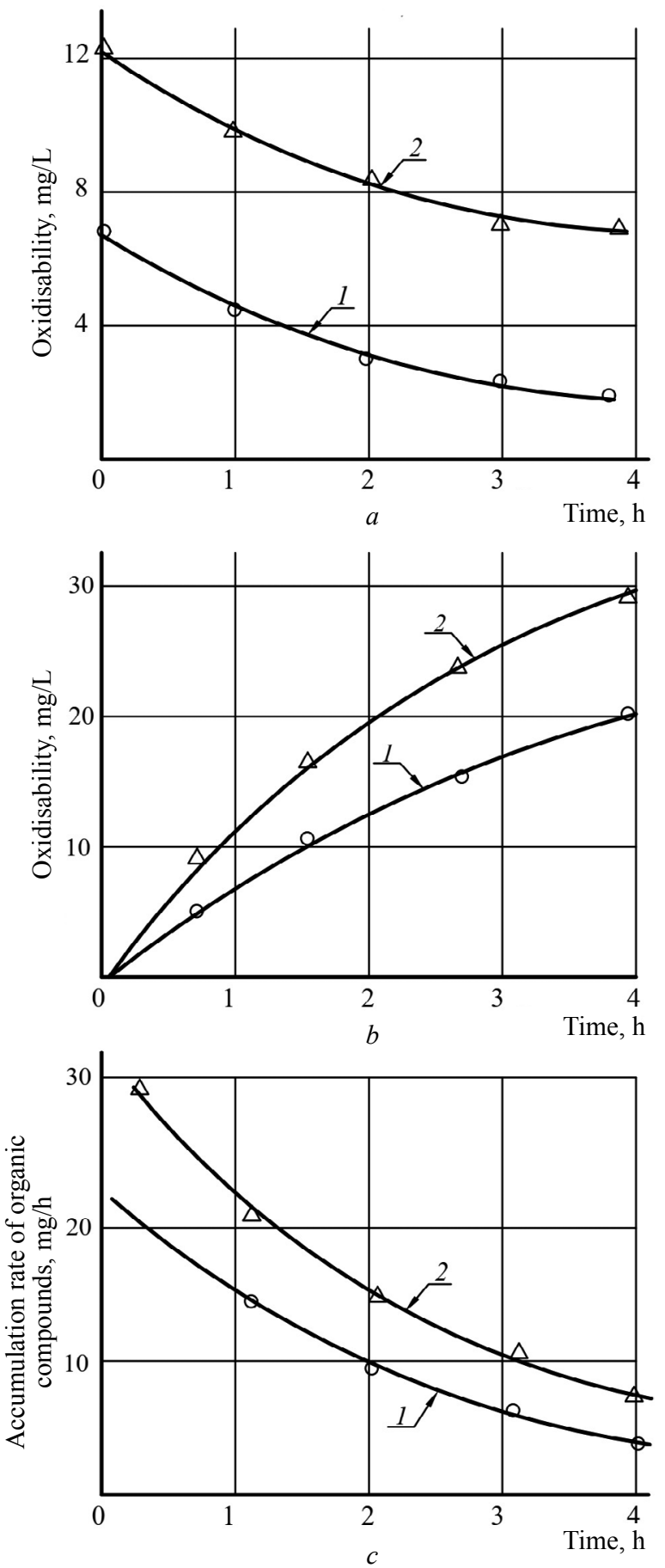

Fig. 11. Deposition rates of colour-forming macromolecular compounds: $a-$ a decrease in the concentration of organic substances during the operation of the membrane unit; $b$ - time dependence of adsorbed organic contaminants; $c$ - determination of the accumulation rates for organic substances in time; 1 - tap water; 2 - river water

Figure 13 shows the absorption spectra of water in the visible spectral range (range 300-850 nanometers) obtained using a KFK-3 spectrophotometer with respect to distilled water. The nature of the organic compounds contained in water can be judged by their colour. The obtained results of the absorption of light with a wavelength of 413 nanometers show the presence of humic substances with a yellow colour. High values of light absorption in other spectral regions indicate the presence of other organic contaminants in water, in particular, iron-organic complexes.

A study of the light absorption spectra in the samples of river (Fig. 13, $a$ ) and tap water (Fig. 13, $b$ ) water demonstrates that, during the bench operation, it is high-molecular compounds that are primarily adsorbed from water. The general picture of membrane pollu- 

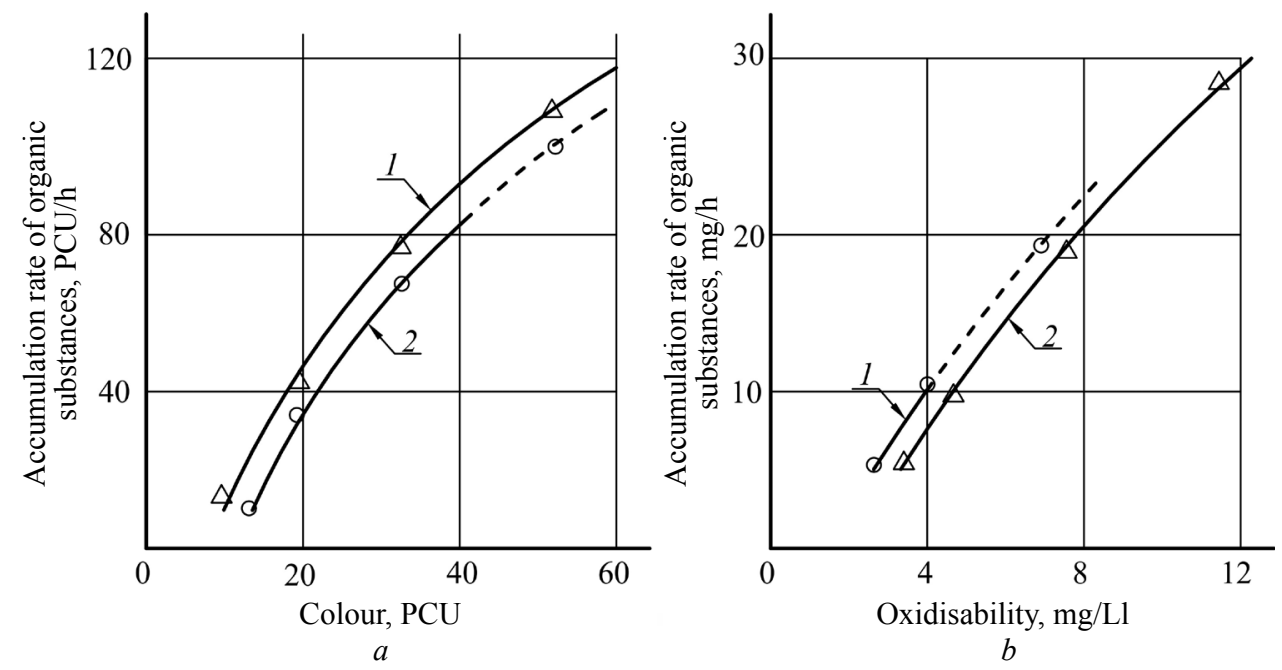

Fig. 12. Adsorption rates of organic substances plotted against their concentrations: $a$ - high molecular weight substances; $b$ - low molecular weight substances; 1 - river water; 2 - tap water

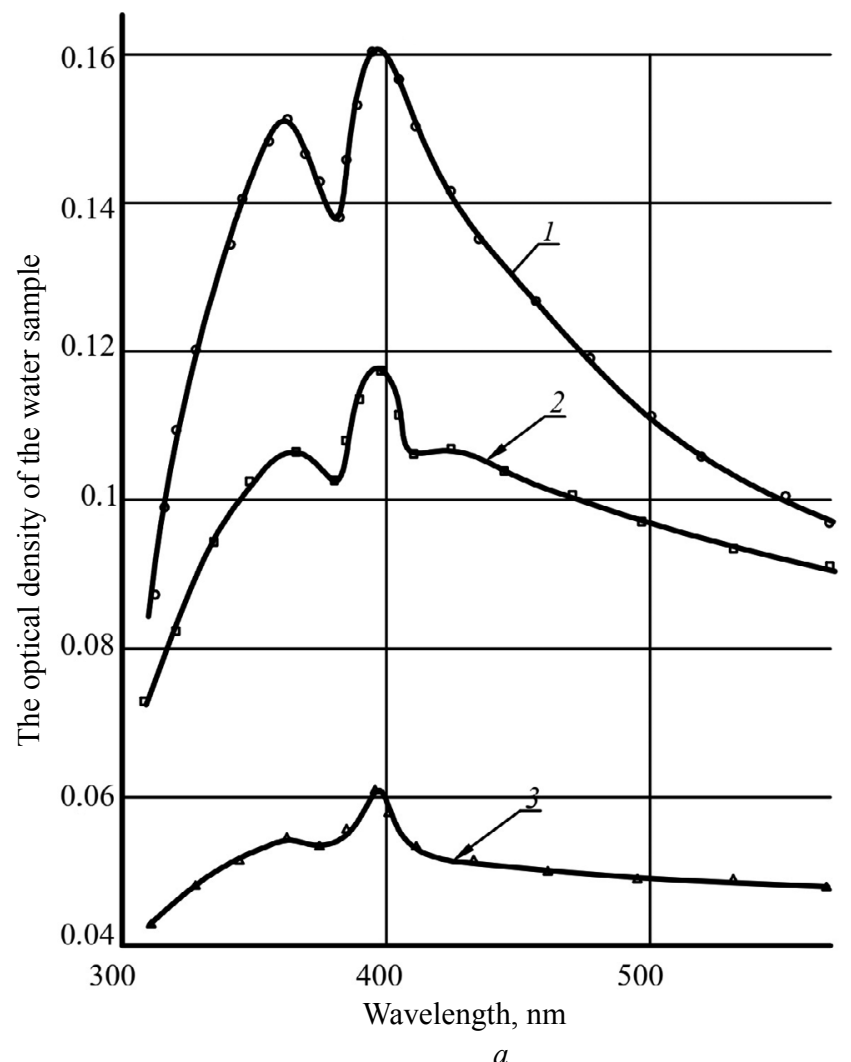

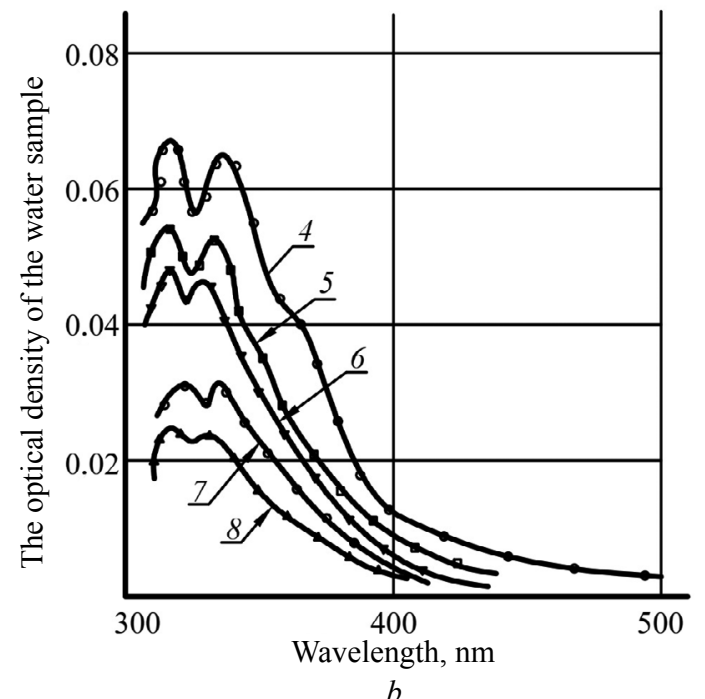

$b$

Fig. 13. Comparison of the optical spectra for river and tap water: $a$ - river water; $b$ - tap water; 1 - river water, colour 56 PCU, oxidisability $12 \mathrm{mg} / \mathrm{L} ; 2$ - water sample 1,1 hour after, colour $40 \mathrm{PCU}$, oxidisability $10 \mathrm{mg} / \mathrm{L} ; 3$ - river water sample 3 hours after, colour 26 PCU, oxidisability $6 \mathrm{mg} / \mathrm{L} ; 4$ - tap water, colour $17 \mathrm{PCU}$, oxidisability $6 \mathrm{mg} / \mathrm{L} ; 5$ - water sample 1, 1 hour after, colour $12 \mathrm{PCU}$, oxidisability $5 \mathrm{mg} / \mathrm{L} ; 6$ - water sample 2, 2 hours after, colour $11 \mathrm{PCU}$, oxidisability $4 \mathrm{mg} / \mathrm{L}$; 7 - nanomembrane filtrate, colour 8 PCU, oxidisability $3.1 \mathrm{mg} / \mathrm{L} ; 8$ - filtrate passed the carbon filter, colour 5 PCU, oxidisability $2.3 \mathrm{mg} / \mathrm{L}$ 


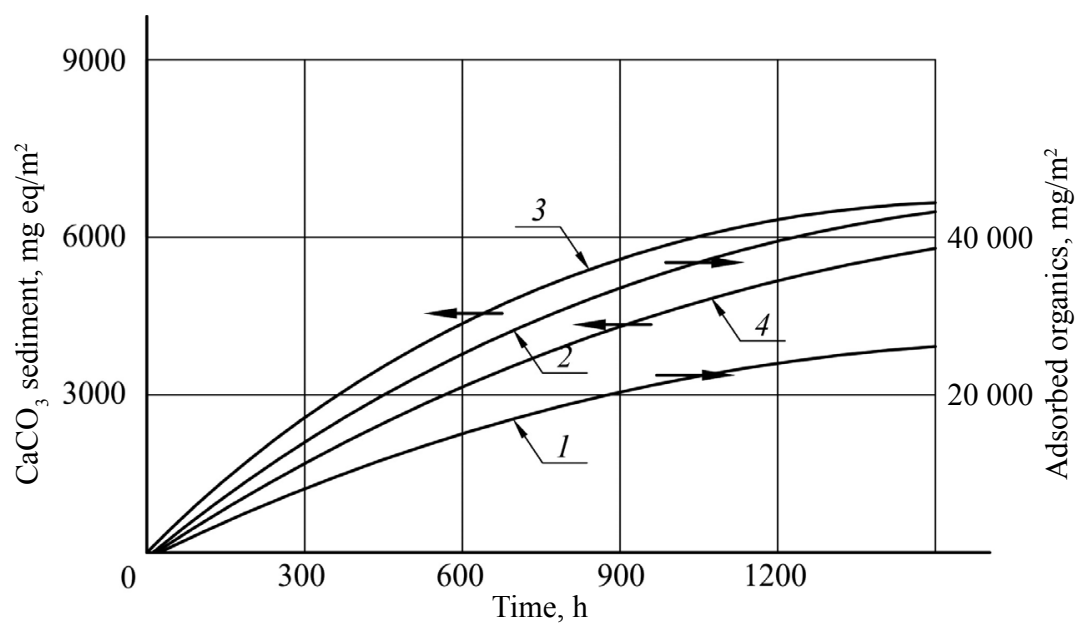

$a$

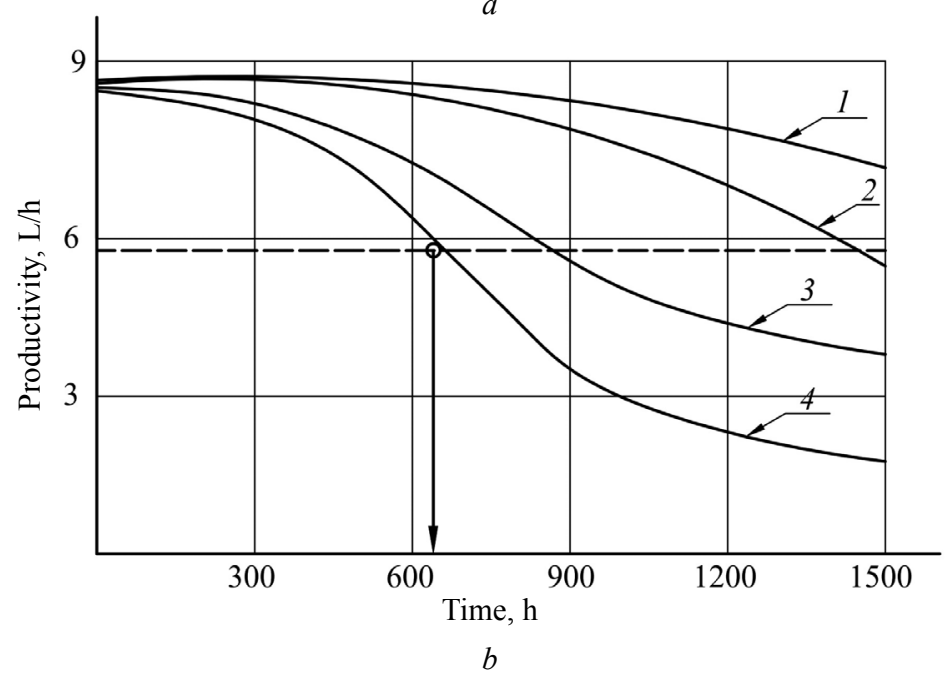

Fig. 14. Prediction of the amount of contamination and a decrease in membrane performance over time: $a$ - the amount of sediments accumulated per $1 \mathrm{~m}^{2}$ of the membrane in time; $b$ - a decrease in the performance of the membrane unit in time; 1 - tap water (after precipitation of organic substances); 2 - river water after removing the suspended substances; 3 - tap water with the dosage of the Aminat-K inhibitor; 4 - tap water without the addition of an inhibitor

tion can vary when other substances are concurrently formed on the membrane, including poorly soluble salts (calcium carbonate), colloidal and organic substances, colloids of iron hydroxide and other membrane sediments [29-38].

Fig. 14 demonstrates the curves obtained by predicting a decrease in membrane performance over time based on previous studies [33-37]. For selecting the operating mode (filter cycle time), one should consider a decrease in the membrane performance and choose a mode in which the productivity drops by $15-20 \%$ [38]. In Fig. 14, a decrease in membrane performance is observed due to the formation of calcium carbonate during the treatment of water of the same salt composition without inhibiting deposition (curve 1) and with the Aminat-K inhibitor (curve 2), as well as during the river (curve 3) and tap (curve 4) water treatment. As can be seen, even when the inhibitor is dosed in the source water, a decrease in the membrane performance due to the formation of the calcium carbonate precipitate is more pronounced that that due to organic deposition. Therefore, when operating membrane units, the formation rate of calcium carbonate should be taken into account [38]. As shown above, organic compounds have a negligible effect on the functioning of membranes; therefore, the membrane deposition control should be carried out primarily on calcium carbonate, without fear of organic deposition [38]. However, when conducting chemical washes, the amount of organic precipitation should be taken into account, and the appropriate amount of chemicals should be selected for alkaline washes [38-40].

\section{DISCUSSION AND CONCLUSIONS}

Reverse osmosis membranes are subject to contamination by organic substances contained in natural waters. Studies have shown the possibility of treating surface waters with a high level of anthropogenic pollution (organochlorine pollutants providing for the oxidis- 
ability of natural waters). When treating surface waters with colour values of up to 70 PCU and oxidisability values of up to $20 \mathrm{mg} / \mathrm{L}$ by reverse osmosis, the formation of membrane organic deposits does not lead to a rapid decrease in membrane performance. Therefore, there is no need to remove organic deposits at the pretreatment stage. Our studies aimed at prediction of membrane performance have shown that, for natural water treatment with colouring of up to $60 \mathrm{PCU}$, the effect of organic substances is much less noticeable than that of crystalline calcium carbonate deposits, even when inhibitors are applied. Therefore, no additional measures preventing the formation of organic sediments are required. Organic contaminants are removed from the membrane surface by chemical washes, simultaneously with regular chemical washes aimed at removing precipitates of sparingly soluble salts (calcium carbonate) and sediments of colloidal substances contained in natural waters.

\section{REFERENCES}

1. Ibrahim Khamis, Rami El-Emam. Nuclear desalination and efficient water management: facing the challenges toward sustainable development. The International Desalination Association World Congress, Sao Paolo,Brazil, REF: IDA17WC-57863_Khamis.

2. Fritzmann C., Lowenberg J., Wintgens T., Melin T. State-of-the-art of reverse osmosis desalination. Desalination. 2007; 216(1-3):1-76. DOI: 10.1016/j.desal.2006.12.009

3. Kaakinen J.W., Moody C.D. Characteristics of reverse-osmosis membrane fouling at the yuma desalting test facility. ACS Symposium Series. 1985; 359-382. DOI: 10.1021/bk-1985-0281.ch027

4. Baker R.W., Cussler E.L., Eykamp W., Koros W.J., Riley R.L., Strathmann H. Membrane separation systems. A research and development needs assessment. United States, 1990. DOI: 10.2172/6885113

5. Winters $\mathrm{H}$. Control of organic fouling at two seawater reverse osmosis plants. Desalination. 1987; 66:319-325. DOI: 10.1016/0011-9164(87)90214-1

6. Taylor J.S. Community and homeowner use of membrane processes. Proceedings of the 1991 Ninth Annual Membr. Conf., Boston, Nov. 4-6. 1991.

7. Cheng R. et al. The effects of sall halogenocarbons on RO mebrane performance. IDA World Conf. on Des. and Water Reuse, August, Washington D.C., Vol. 2.

8. Ricci B.C., Ferreira C.D., Marques L.S., Martins S.S., Reis B.G., Amaral M.C.S. Assessment of the chemical stability of nanofiltration and reverse osmosis membranes employed in treatment of acid gold mining effluent. Separation and Purification Technology. 2017; 174:301-311. DOI: 10.1016/j.seppur.2016.11.007

9. Simon F.X., Penru Y., Mico M.M., Llorens J., Esplugas S., Baig S. Biological activity in expanded clay (EC) and granulated activated carbon (GAC) seawater filters. Desalination. 2013; 328:67-73. DOI: 10.1016/j. desal.2013.08.018

10. Armendáriz-Ontiveros M.M., García García A., de los Santos Villalobos S., Fimbres Weihs G.A. Biofouling performance of RO membranes coated with Iron NPs on graphene oxide. Desalination. 2019; 451:45-58. DOI: 10.1016/j.desal.2018.07.005

11. Kim L.H., Nava-Ocampo M., van Loosdrecht M.C.M., Kruithof J.C., Vrouwenvelder J.C. The membrane fouling simulator: development, application, and early-warning of biofouling in RO treatment. Desalination and Water Treatment. 2018; 126:1-23. DOI: 10.5004/dwt.2018.23081

12. Katebian L., Gomez E., Skillman L., Li D., Ho G., Jiang S.C. Inhibiting quorum sensing pathways to mitigate seawater desalination RO membrane biofouling. Desalination. 2016; 393:135-143. DOI: 10.1016/j. desal.2016.01.013

13. Poussade Y., Vergnolle F., Baaklini D., Pitt N., Gaid A., Ventresque C., Vigneron-Larosa N. Impact of granular media vs membrane filtration on the pretreatment of SWRO desalination plants. The Inter national Desalination Association World Congress - San Paulo, Brazil. REF: IDA 17 WC-57853 Poussade.

14. Siebdrath N., Farhat N., Ding W., Kruithof J., Vrouwenvelder J.S. Impact of membrane biofouling in the sequential development of performance indicators: Feed channel pressure drop, permeability, and salt rejection. Journal of Membrane Science. 2019; 585:199-207. DOI: 10.1016/j.memsci.2019.05.043

15. Saffarimiandoab F., Gul B.Y., Erkoc-Ilter S., Guclu S., Unal S., Tunaboylu B. et al. Evaluation of biofouling behavior of zwitterionic silane coated reverse osmosis membranes fouled by marine bacteria. Progress in Organic Coatings. 2019; 134:303-311. DOI: 10.1016/j.porgcoat.2019.05.027

16. Lee H., Jin Y., Hong S. Recent transitions in ultrapure water (UPW) technology: Rising role of reverse osmosis (RO). Desalination. 2016; 399:185-197. DOI: 10.1016/j.desal.2016.09.003.

17. Shrivastava A., Rosenberg S., Peery M. Energy efficiency breakdown of reverse osmosis and its implications on future innovation roadmap for desalination. Desalination. 2015; 368:181-192. DOI: 10.1016/j. desal.2015.01.005 
18. Al-Amoudi A.S. Factors affecting natural organic matter (NOM) and scaling fouling in NF membranes: A review. Desalination. 2010; 259:1-10. DOI: 10.1016/j.desal.2010.04.003

19. Kumar M., Adham S.S., Pearce W.R. Investigation of seawater reverse osmosis fouling and its relationship to pretreatment type. Environmental Science \& Technology. 2006; 40(6):2037-2044. DOI: 10.1021/ es0512428

20. Guastalli A.R., Simon F.X., Penru Y., de Kerchove A., Llorens J., Baig S. Comparison of DMF and UF pre-treatments for particulate material and dissolved organic matter removal in SWRO desalination. Desalination. 2013; 322:144-150. DOI: 10.1016/j.desal.2013.05.005

21. Yang J., Lee S., Lee E., Lee J., Hong S. Effect of solution chemistry on the surface property of reverse osmosis membranes under seawater conditions. Desalination. 2009; 247(1-3):148-161. DOI: 10.1016/j. desal.2008.12.020

22. Knops F., Pozzi J., Dharmabalan D. TOC and Color removal from surface water with hollow fiber nanofiltration. The international Desalination Association World Congress - Sao Paulo, Brazil, REF: IDA $17 \mathrm{WC}-57848$ Knops.

23. Wen Y., Chen Y., Wu Z., Liu M., Wang Z. Thin-film nanocomposite membranes incorporated with water stable metal-organic framework CuBTTri for mitigating biofouling. Journal of Membrane Science. 2019; 582:289-297. DOI: 10.1016/j.memsci.2019.04.016

24. Yurchevskiy Y.B., Pervov A.G., Pichugina M.A. Water purification from organic pollution using membrane water treatment technologies. Energy Saving and Water Treatment. 2016; 5(103):32-45. (rus.).

25. Bian R., Yamomoto K., Watanabe Y. The effect of shear rate on controlling the concentration polarization and membrane fouling. Desalination. 2000; 131(1 3):225-236. DOI: 10.1016/s0011-9164(00)90021-3

26. Laine J.-M., Vial D., Moulart P. Status after 10 years of operation - overview of UF technology today. Desalination. 2000; 131(1-3):17-25. DOI: 10.1016/ s0011-9164(00)90002-x

27. Pontie M., Buisson H., Diawara C.K., EssisTome H. Studies of halide ions mass transfer in nanofiltration - application to selective defluorination of brackish drinking water. Desalination. 2003; 157(13):127-134. DOI: 10.1016/s0011-9164(03)00391-6

28. Ducom G., Cabassud C. Interests and limitations of nanofiltration for the removal of volatile organic compounds in drinking water production. Desalination. 1999; 124(1-3):115-123. DOI: 10.1016/s00119164(99)00095-8

29. Itoh M., Kunikane S., Magara Y. Evaluation of nanofiltration for disinfection by-products control in drinking water treatment. Water Science and Technolo- gy: Water Supply. 2001; 1(5-6):233-243. DOI: $10.2166 /$ ws.2001.0119

30. Boussahel F.R., Bouland S., Moussaoui K.M., Montiel A. Removal of pesticide residues in water using the nanofiltration process. Desalination. 2000; 132(13):205-209. DOI: 10.1016/s0011-9164(00)00151-x

31. Bonne P.A.C., Beerendonk E.F., van der Hoek J.P., Hofman J.A.M.H. Retention of herbicides and pesticides in relation to aging of RO membranes. Desalination. 2000; 132(1-3):189-193. DOI: 10.1016/ s0011-9164(00)00148-x

32. Thanuttamavong M., Oh J.I., Yamamoto K., Urase T. Comparison between rejection characteristics of natural organic matter and inorganic salts in ultra low pressure nanofiltration for drinking water production. Water Science and Technology: Water Supply. 2001; 1(1-6):77-90. DOI: 10.2166/ws.2001.0102

33. Yurchevskiy E.B., Pervov A.G., Andrianov A.P., Pichugina M.A. Study of the technological characteristics of membrane elements with open pressure channels. Thermal Engineering. 2009; 11:46-52. (rus.).

34. Pervov A.G. A simplified RO process design based on understanding of fouling mechanisms. Desalination. 1999; 127(1-3):227-247. DOI: 10.1016/s00119164(99)00179-4

35. Pervov A.G., Andrianov A.P., Spitsov D.V., Yurchevskiy E.B. Effect of membrane properties and membrane channel design on the intensity of sedimentation processes and performance degradation. Membranes. 2010; 2:3-14. (rus.).

36. Champlin T.L. Using circulation tests to model natural organic matter adsorption and particle deposition by spiral-wound nanofiltration membrane elements. Desalination. 2000; 131(1-3):105-115. DOI: 10.1016/ s0011-9164(00)90011-0

37. Pervov A.G., Andrianov A.P., Spitsov D.V., Rudakova L.V. New ultrafiltration and nanofiltration membrane techniques and facilities for city buildings water supply and heating. Water Supply and Sanitary Technique. 2009; 7:12-19.

38. Pervov A.G., Rudakova G.Ya., Yefremov R.V. Development of programs for the process of calculating the reverse osmosis and nanofiltration systems using reagents "Aminat". Water Supply and Sanitary Technique. 2009; 7:21-28. (rus.).

39. David Lawrence Russell, Membrane autopsies as investigative tool to improve cleaning and system performance. A case study. The International Desalination Association World Congress - Sao Paolo, Brazil, REF: IDA17WC-58273_Russell.

40. Darton T., Annunziata U., Pisano F.D.V., Gallego S. Membrane autopsy helps to provide solutions to operational problems. Desalination. 2004; 167:239-245. DOI: 10.1016/j.desal.2004.06.133 
Received May 22, 2019.

Adopted in its final form on July 4, 2019.

Approved for publication on August 29, 2019.

B I o n o t e s : Yu Dan Su - director; RAIFIL China, CSM official representative in Russia; room 206, Cheng Wen Business Building, No. 4285, Shen Du Rd, Ming Hang District, Shanghai, 201112, China; raifil@yandex.ru;

Alexei G. Pervov - Doctor of Technical Sciences, Professor of the Department of Water Supply and Sanitation; Moscow State University of Civil Engineering (National Research University) (MGSU); 26 Yaroslavskoe shosse, Moscow, 129337, Russian Federation; PervovAG@mgsu.ru;

Xuan Quyet Nguyen - Ph.D. student of the Department of Water Supply and Sanitation; Moscow State University of Civil Engineering (National Research University) (MGSU); 26 Yaroslavskoe shosse, Moscow, 129337, Russian Federation; voda@mgsu.ru.

\section{ЛИТЕРАТУРА}

1. Ibrahim Khamis, Rami El-Emam. Nuclear desalination and efficient water management: facing the challenges toward sustainable development // The International Desalination Association World Congress, Sao Paolo, Brazil, REF: IDA17WC-57863_Khamis.

2. Fritzmann C., Lowenberg J., Wintgens T., Melin T. State-of-the-art of reverse osmosis desalination // Desalination. 2007. Vol. 216. Issue 1-3. Pp. 1-76. DOI: 10.1016/j.desal.2006.12.009

3. Kaakinen J.W., Moody C.D. Characteristics of reverse-osmosis membrane fouling at the yuma desalting test facility // ACS Symposium Series. 1985. Pp. 359-382. DOI: 10.1021/bk-1985-0281.ch027

4. Baker R.W., Cussler E.L., Eykamp W., Koros W.J., Riley R.L., Strathmann H. Membrane Separation Systems - A research and development Needs Assessment. United States, 1990. DOI: 10.2172/6885113

5. Winters $H$. Control of organic fouling at two seawater reverse osmosis plants // Desalination. 1987. Vol. 66. Pp. 319-325. DOI: 10.1016/00119164(87)90214-1

6. Taylor J.S. Community and homeowner use of membrane processes // Proceedings of the 1991 Ninth Annual Membr. Conf., Boston, Nov. 4-6, 1991.

7. Cheng $R$. et al. The effects of small halogenocarbons on RO membrane performance // IDA World Conf. on Des. and Water Reuse, August, Washington D.C., Vol. 2.

8. Ricci B.C., Ferreira C.D., Marques L.S., Martins S.S., Reis B.G., Amaral M.C.S. Assessment of the chemical stability of nanofiltration and reverse osmosis membranes employed in treatment of acid gold mining effluent // Separation and Purification Technology. 2017. Vol. 174. Pp. 301-311. DOI: 10.1016/j.seppur.2016.11.007

9. Simon F.X., Penru Y., Mico M.M., Llorens J., Esplugas S., Baig S. Biological activity in expanded clay (EC) and granulated activated carbon (GAC) seawater filters // Desalination. 2013. Vol. 328. Pp. 67-73. DOI: 10.1016/j.desal.2013.08.018

10. Armendáriz-Ontiveros M.M., García García A., de los Santos Villalobos S., Fimbres Weihs G.A. Biofouling performance of RO membranes coated with Iron NPs on graphene oxide // Desalination. 2019. Vol. 451. Pp. 45-58. DOI: 10.1016/j.desal.2018.07.005

11. Kim L.H., Nava-Ocampo M., van Loosdrecht M.C.M., Kruithof J.C., Vrouwenvelder J.C. The membrane fouling simulator: development, application, and early-warning of biofouling in RO treatment // Desalination and Water Treatment. 2018. Vol. 126. Pp. 1-23. DOI: 10.5004/dwt.2018.23081

12. Katebian L., Gomez E., Skillman L., Li D., Ho G., Jiang S.C. Inhibiting quorum sensing pathways to mitigate seawater desalination RO membrane biofouling // Desalination. 2016. Vol. 393. Pp. 135-143. DOI: 10.1016/j.desal.2016.01.013

13. Poussade Y., Vergnolle F., Baaklini D., Pitt N., Gaid A., Ventresque C., Vigneron-Larosa N. Impact of granular media vs membrane filtration on the pretreatment of SWRO desalination plants // The International Desalination Association World Congress, San Paulo, Brazil. REF: IDA 17 WC-57853_Poussade.

14. Siebdrath N., Farhat N., Ding W., Kruithof J., Vrouwenvelder J.S. Impact of membrane biofouling in the sequential development of performance indicators: Feed channel pressure drop, permeability, and salt rejection // Journal of Membrane Science. 2019. Vol. 585. Pp. 199-207. DOI: 10.1016/j.memsci.2019.05.043

15. Saffarimiandoab F., Gul B.Y., Erkoc-Ilter S., Guclu S., Unal S., Tunaboylu B. et al. Evaluation of biofouling behavior of zwitterionic silane coated reverse osmosis membranes fouled by marine bacteria // Progress in Organic Coatings. 2019. Vol. 134. Pp. 303-311. DOI: $10.1016 /$ j.porgcoat.2019.05.027

16. Lee H., Jin Y., Hong S. Recent transitions in ultrapure water (UPW) technology: Rising role of re- 
verse osmosis (RO) // Desalination. 2016. Vol. 399. Pp. 185-197. DOI: 10.1016/j.desal.2016.09.003

17. Shrivastava A., Rosenberg S., Peery M. Energy efficiency breakdown of reverse osmosis and its implications on future innovation roadmap for desalination // Desalination. 2015. Vol. 368. Pp. 181-192. DOI: 10.1016/j.desal.2015.01.005

18. Al-Amoudi A.S. Factors affecting natural organic matter (NOM) and scaling fouling in NF membranes: A review // Desalination. 2010. Vol. 259. Pp. 1-10. DOI: 10.1016/j.desal.2010.04.003

19. Kumar M., Adham S.S., Pearce W.R. Investigation of seawater reverse osmosis fouling and its relationship to pretreatment type // Environmental Science \& Technology. 2006. Vol. 40. Issue 6. Pp. 2037-2044. DOI: $10.1021 / \mathrm{es} 0512428$

20. Guastalli A.R., Simon F.X., Penru Y., de Kerchove A., Llorens J., Baig $S$. Comparison of DMF and UF pre-treatments for particulate material and dissolved organic matter removal in SWRO desalination // Desalination. 2013. Vol. 322. Pp. 144-150. DOI: 10.1016/j. desal.2013.05.005

21. Yang J., Lee S., Lee E., Lee J., Hong S. Effect of solution chemistry on the surface property of reverse osmosis membranes under seawater conditions // Desalination. 2009. Vol. 247. Issue 1-3. Pp. 148-161. DOI: 10.1016/j.desal.2008.12.020

22. Knops F., Pozzi J., Dharmabalan D. TOC and Color removal from surface water with hollow fiber nanofiltration // The international Desalination Association World Congress - Sao Paulo, Brazil, REF: IDA 17 WC - 57848_Knops.

23. Wen Y., Chen Y., Wu Z., Liu M., Wang Z. Thin-film nanocomposite membranes incorporated with water stable metal-organic framework CuBTTri for mitigating biofouling // Journal of Membrane Science. 2019. Vol. 582. Pp. 289-297. DOI: 10.1016/j.memsci.2019.04.016

24. Юрчевский Е.Б., Первов А.Г., Пичугина М.A. Очистка воды от органических загрязнений с использованием мембранных технологий водоподготовки // Энергосбережение и водоподготовка. 2016. № 5 (103). C. 32-45.

25. Bian R., Yamomoto K., Watanabe Y. The effect of shear rate on controlling the concentration polarization and membrane fouling // Desalination. 2000. Vol. 131. Issue 1-3. Pp. 225-236. DOI: 10.1016/s00119164(00)90021-3

26. Laine J.-M., Vial D., Moulart P. Status after 10 years of operation - overview of UF technology today // Desalination. 2000. Vol. 131. Issue 1-3. Pp. 17 25. DOI: 10.1016/s0011-9164(00)90002-x

27. Pontie M., Buisson H., Diawara C.K., Essis-Tome H. Studies of halide ions mass transfer in nanofiltration - application to selective defluorina- tion of brackish drinking water // Desalination. 2003. Vol. 157. Issue 1-3. Pp. 127-134. DOI: 10.1016/s00119164(03)00391-6

28. Ducom G., Cabassud C. Interests and limitations of nanofiltration for the removal of volatile organic compounds in drinking water production // Desalination. 1999. Vol. 124. Issue 1-3. Pp. 115-123. DOI: 10.1016/ s0011-9164(99)00095-8

29. Itoh M., Kunikane S., Magara Y. Evaluation of nanofiltration for disinfection by-products control in drinking water treatment // Water Science and Technology: Water Supply. 2001. Vol. 1. Issue 5-6. Pp. 233243. DOI: 10.2166/ws.2001.0119

30. Boussahel F.R., Bouland S., Moussaoui K.M., Montiel $A$. Removal of pesticide residues in water using the nanofiltration process // Desalination. 2000. Vol. 132. Issue 1-3. Pp. 205-209. DOI: 10.1016/s00119164(00)00151-x

31. Bonne P.A.C., Beerendonk E.F., van der Hoek J.P., Hofman J.A.M.H. Retention of herbicides and pesticides in relation to aging of RO membranes // Desalination. 2000. Vol. 132. Issue 1-3. Pp. 189-193. DOI: 10.1016/s0011-9164(00)00148-X

32. Thanuttamavong M., Oh J.I., Yamamoto K., Urase T. Comparison between rejection characteristics of natural organic matter and inorganic salts in ultra low pressure nanofiltration for drinking water production // Water Science and Technology: Water Supply. 2001. Vol. 1. Issue 1-6. Pp. 77-90. DOI: 10.2166/ ws.2001.0102

33. Юрчевский Е.Б., Первов А.Г., Андрианов А.П., Пичугина М.А. Исследование технологических характеристик мембранных элементов с «открытыми» напорными каналами // Теплоэнергетика. 2009. № 11. С. 46-52.

34. Pervov A.G. A simplified RO process design based on understanding of fouling mechanisms // Desalination. 1999. Vol. 127. Issue 1-3. Pp. 227-247. DOI: 10.1016/s0011-9164(99)00179-4

35. Первов А.Г., Андрианов А.П., Спицуов Д.В., Юрчевский Е.Б. Влияние свойств мембран и конструкции мембранных каналов на интенсивность процессов осадкообразования и снижение производительности // Мембраны. 2010. № 2. С. 3-14.

36. Champlin T.L. Using circulation tests to model natural organic matter adsorption and particle deposition by spiral-wound nanofiltration membrane elements // Desalination. 2000. Vol. 131. Issue 1-3. Pp. 105-115. DOI: 10.1016/s0011-9164(00)90011-0

37. Первов А.Г., Андрианов А.П., Спицов Д.В., Рудакова Л.В. Новые технологии и аппараты на основе методов ультра- и нанофильтрации для систем водоснабжения и теплоснабжения // Водоснабжение и санитарная техника. 2009. № 7. С. 12-19. 
38. Первов А.Г., Рудакова Г.Я., Ефремов Р.В. Разработка программ для технологического расчета систем обратного осмоса и нанофильтрации с использованием реагентов «Аминат» // Водоснабжение и санитарная техника. 2009. № 7. С. 21-28.

39. David Lawrence Russell. Membrane autopsies as investigative tool to improve cleaning and system performance. A case study. The International Desalination Association World Congress — Sao Paolo, Brazil, REF: IDA17WC-58273_Russell.

40. Darton T., Annunziata U., Pisano F.D.V., Gallego $S$. Membrane autopsy helps to provide solutions to operational problems // Desalination. 2004. Vol. 167. Pp. 239-245. DOI: 10.1016/j.desal.2004.06.133

Поступила в редакцию 22 мая 2019 г.

Принята в доработанном виде 4 июля 2019 г.

Одобрена для публикачии 29 августа 2019 г.

О в а в Т О РА X : Ю Дан Cy - директор; «RAIFIL China» - официальный представитель компании CSM в России; 201112, Шанхай, р-н Мин Ханг, Шен Ду Роуд, 4285, Ченг Вен Бизнес Билдинг, оф. 206, Китай; raifil@ yandex.ru;

Алексей Германович Первов - доктор технических наук, профессор кафедры водоснабжения и водоотведения; Национальный исследовательский Московский государственный строительный университет (НИУ МГСУ); 129337, г. Москва, Ярославское шоссе, д. 26; PervovAG@mgsu.ru;

Суан Кует Нгуен - аспирант кафедры водоснабжения и водоотведения; Национальный исследовательский Московский государственный строительный университет (НИУ МГСУ); 129337, г. Москва, Ярославское шоссе, д. 26; voda@mgsu.ru. 